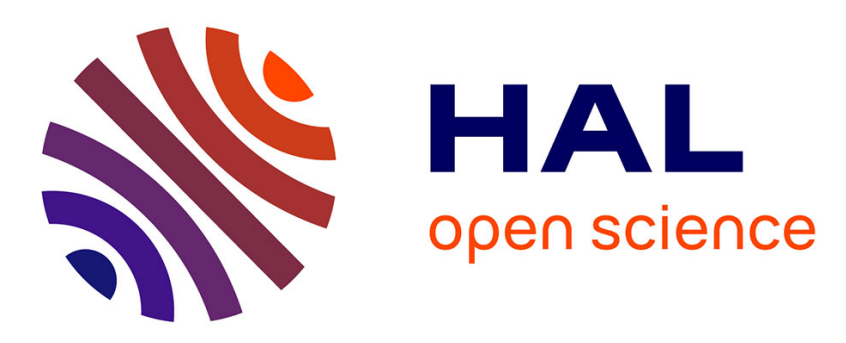

\title{
Evolutionary significance of the blastozoan Eumorphocystis and its pseudo-arms
}

Thomas Guensburg, James Sprinkle, Rich Mooi, Bertrand Lefebvre

\section{To cite this version:}

Thomas Guensburg, James Sprinkle, Rich Mooi, Bertrand Lefebvre. Evolutionary significance of the blastozoan Eumorphocystis and its pseudo-arms. Journal of Paleontology, 2021, 95 (2), pp.327-343. 10.1017/jpa.2020.84 . hal-03004489

\section{HAL Id: hal-03004489 https://hal.science/hal-03004489}

Submitted on 13 Nov 2020

HAL is a multi-disciplinary open access archive for the deposit and dissemination of scientific research documents, whether they are published or not. The documents may come from teaching and research institutions in France or abroad, or from public or private research centers.
L'archive ouverte pluridisciplinaire HAL, est destinée au dépôt et à la diffusion de documents scientifiques de niveau recherche, publiés ou non, émanant des établissements d'enseignement et de recherche français ou étrangers, des laboratoires publics ou privés. 
1 Evolutionary significance of the blastozoan Eumorphocystis and its

2 pseudo-arms

4 Thomas E. Guensburg ${ }^{1}$, James Sprinkle ${ }^{2}$, Rich Mooi ${ }^{3}$, and Bertrand Lefebvre ${ }^{4}$

$6 \quad{ }^{1}$ IRC, Field Museum, 1400 South Lake Shore Drive, Chicago, IL 60605 (tguensburg@fieldmuseum.org)

$8 \quad{ }^{2}$ Department of Geological Sciences, Jackson School of Geosciences, University of Texas, 1 University

9 Station C1100, Austin, TX 78712-0254 (echino@jsg.utexas.edu)

$11{ }^{3}$ Department of Invertebrate Zoology, California Academy of Sciences, 55 Music Concourse Drive, San

12 Francisco, CA 94118 (rmooi@calacademy.org)

$14{ }^{4}$ Univ Lyon, Univ Lyon 1, ENSL, CNRS, LGL-TPE, F69622, Villeurbanne, France

15 (bertrand.lefebvre@univ-lyon1.fr)

17 Running header: Eumorphocystis, pseudo-arms, homoplasy with crinoids

19 Abstract. - Twelve Eumorphocystis specimens provide the basis for new findings and a more

20 informed assessment of whether this blastozoan (eocrinoids, blastoids, diploporites,

21 rhombiferans) constitutes the sister taxon to crinoids, as has been recently proposed. Both

22 Eumorphocystis and earliest-known crinoid feeding appendages express large longitudinal

23 canals, a demonstrable homology exclusive to these taxa. However, the specimen series studied

24 here shows that Eumorphocystis canals constrict proximally and travel within ambulacrals above 
25 the thecal cavity. This relationship is congruent with a documented blastozoan pattern but very

26 unlike earliest crinoid topology. Earliest crinoid arm cavities lie fully beneath floor plates; these

27 expand and merge directly with the main thecal coelomic cavity at thecal shoulders. Other

28 associated anatomical features echo this contrasting comparison. Feeding appendages of

29 Eumorphocystis lack two-tiered cover plates, podial basins/pores, and lateral arm plating, all

30 features of earliest crinoid "true arms". Eumorphocystis feeding appendages are buttressed by

31 solid block-like plates added during ontogeny at a generative zone below floor plates, a pattern

32 with no known parallel among crinoids. Eumorphocystis feeding appendages express brachioles,

33 erect extensions of floor plates, also unknown among crinoids. These several distinctions point to

34 non-homology of most feeding appendage anatomy, removing Eumorphocystis and other

35 blastozoans from exclusive relationship with crinoids. Eumorphocystis further differs from

36 crinoids in that thecal plates express diplopores, respiratory structures not present among

37 crinoids, but ubiquitous among certain groups of blastozoans. Phylogenetic analysis places

38 Eumorphocystis as a crownward blastozoan, far removed from crinoids.

\section{Introduction}

42

43 It was suggested long ago that blastozoans (eoccrinoids, blastoids, diploporites,

44 rhombiferans) and crinoids comprise a monophyletic assemblage, the so-called Pelmatozoa

45 (Leuckart, 1846), largely on the basis of common possession of a superficially similar

46 attachment stalk. In spite of doubts about this interpretation that arose during the mid- $20^{\text {th }}$

47 century (Ubaghs, 1953, 1968; Sprinkle, 1973), this canon was perpetuated in major reference 
48 works such as the Treatise on Invertebrate Paleontology and persists in many publications to the

49 present day. Works seeking to separate blastozoans and crinoids as only distantly related

50 pentaradiate forms or reject the pelmatozoan hypotheses that crinoids and blastozoans share

51 exclusive common ancestry, have met with considerable resistance (Clausen et al., 2009; Zamora

52 and Smith, 2011; Kammer et al., 2013; Sumrall, 2017; Sheffield and Sumrall, 2019a, 2019b;

53 inter alia).

54 However, even detractors of the idea that crinoids and blastozoans are only superficially

55 similar and do not form an exclusive clade seem to have accepted the importance of the crucial

56 suite of feeding appendage features cited by those who question the validity of Pelmatozoa, or at

57 least argue that any resemblances are superficial (Mooi and David, 1998, 2000; David and Mooi,

58 1999; Guensburg and Sprinkle, 2007; Guensburg et al., 2020, inter alia). For example,

59 proponents for blastozoan ancestry of crinoids claimed an unnamed Middle Cambrian blastozoan

60 represented only by disarticulated plates provided evidence that somatocoelar extensions from

61 the main body cavity continued into the arms (Clausen, 2009). However, it is also clear these

62 supposed blastozoan arms lacked any extraxial elements. The purported coelomic canals pass

63 through floor plates toward the peristome, not through the thecal shoulder, which is an anatomy

64 unlike crinoids. The diminutive nature of these blastozoan canals is also problematic. Other

65 workers cited this and other evidence to reject the idea that any canals within the appendages of

66 blastozoans represented spaces for somatocoelar extensions (Guensburg et al., 2010). In spite of

67 attempts to clarify the issue through precise anatomical descriptions, the debate continues. Here,

68 we shed new light on another purported "missing link" between crinoids and blastozoans.

69 Recently, a proposal that Eumorphocystis multiporata Branson and Peck, 1940,

70 (hereafter, Eumorphocystis, as all specimens are conspecific topotypes), a diplopore-bearing 
71 blastozoan, represents the nearest-known sister group to crinoids has been published (Sheffield

72 and Sumrall, 2019). Evidence central to this suggestion, largely derived from a single specimen,

73 is the description of a longitudinal canal within each of this taxon's feeding appendages. These

74 canals are stated to pierce the theca and connect with the thecal coelomic cavity in a manner

75 similar to that known for crinoids (Sheffield and Sumrall, 2019).

76 Two ancillary putative homologies follow: "arm" construction consisting of triserial (here

77 referred to as tripartite, because an aboral series is not in strict one-to-one sequence with the

78 other two) axial and extraxial elements, and the presence of "radial" plates from which an aboral

79 uniserial set of "brachial" extraxial elements extends distally out these appendages. We

80 reconsider and test this proposal using new and existing observations from 12 Eumorphocystis

81 specimens. These data are then compared with an expanded update of early crinoid arm

82 morphology recently made available through examination of earliest crinoids. These data have

83 only recently been more fully explicated in the context of crinoid origins (Guensburg et al.,

84 2020).

85 A full understanding of the feeding appendages of Eumorphocystis has been a long-term

86 process, and even now some details, such as their full length, remain unknown (Fig. 1). The

87 original description of Eumorphocystis (Branson and Peck, 1940) was based on the holotype

88 alone, in which the appendages are broken off close to the theca. This led to the initial

89 conclusion that exothecal feeding appendages were lacking in this taxon. More complete

90 Eumorphocystis specimens provided the first evidence of "arms" (Parsley, 1982). Initially, these

91 were considered of blastozoan origin and only homoplastic on crinoid arms (Parsley, 1982).

92 Recently, the discovery that early crinoids express what could also be considered a tripartite

93 pattern (Guensburg and Sprinkle, 2009) formed the basis for a reinterpretation that 
94 Eumorphocystis "arm" anatomy is homologous to that of early crinoids (Sheffield and Sumrall,

95 2019a). In this paper, however, we add descriptive data and imagery that enhance our

96 understanding of, and provide a basis for, interpretation of Eumorphocystis "arms" that is in

97 agreement with the original suggestion that Eumorphocystis is of strictly blastozoan affinity

98 (Parsley, 1982). The present data confirm most of the basic "arm" construction details, but reveal

99 significant points of departure, particularly at the juncture of arms to theca (Sheffield and

100 Sumrall, 2019a). This new information forms the core of our reappraisal of the evolutionary

101 significance of Eumorphocystis.

102

103

Repositories, Material, Stratigraphic Occurrence, and Methods

104

105

Specimens used for this study were selected to provide data concerning feeding

appendage and associated thecal anatomy. Virtually no additional preparation beyond that

107 already accomplished was needed. Specimens were photographed using a Leica dms 300 digital

108 camera fitted with stacking capability.

109 Repositories and institutional abbreviations. - Eumorphocystis specimens used in this

110 study are housed in the collections of the Sam Noble Museum (OU), University of Oklahoma,

111 Norman, and the Non-vertebrate Paleontology Lab (----TX--, NPL) at the University of Texas,

112 Austin. These twelve topotypes are: OU 9047, OU 9048, OU 9049, OU 238156, OU 238157,

113 OU 238158, OU 238159, 1107TX2, 1279TX126, 1279TX339, 1404TX6, and NPL 93144 (Table

114 1). We also examined a plaster cast of the holotype, OU 3123. Codings for other taxa used in the

115 phylogenetic analysis were primarily obtained from published sources and checked with 
116 specimens in the collections of the Field Museum, Chicago, and the Non-vertebrate Paleontology

117 Laboratory at the University of Texas, Austin.

All Eumorphocystis specimens were collected from the Lower Echinoderm Zone,

119 Mountain Lake Member, Bromide Formation, Arbuckle Mountains, Oklahoma. Detailed locality

120 data are available from respective repositories. The Bromide Formation is Sandbian, early Late

121 Ordovician, in age.

122

123 Preservation and Taphonomy

124

Most Eumorphocystis specimens were surface collected and largely free from enclosing

126 calcareous shale, but a few are preserved on carbonate grainstone surfaces. Specimens are

127 usually three dimensional or nearly so, with negligible crushing. No specimen preserved with

128 complete feeding appendages or stems is known. Instead, available material consists of thecae

129 with arms broken off at varying distances from the theca. The different breakage patterns are

130 important for tracing features such as those involved in the transition from theca to appendage.

131 Only a few specimens preserve proximal portions of the stem, the longest-known segment with

13231 "columnals". Specimens show variable amounts of grainy calcite overgrowths and spar

133 infilling of stereom, presumably the result of rapid post-mortem cementation. This is not a

134 serious impediment for observing anatomy such as thecal plate sutures, but it can obscure details

135 of microscopic structures germane to assessing the features crucial to determining the

136 evolutionary significance of Eumorphocystis. In some cases, there are no apparent canals in the

137 thecal or near-thecal portions of the ambulacra. In a few cases, specimens corroded by

138 differential dissolution weathering, presumably resulting from more soluble low magnesium 
139 cement versus high-magnesium echinoderm stereom, reveal tiny canals. These are continuations

140 of larger feeding appendage canals. In addition, the twelve specimens available furnish data on

141 intraspecific variation. These findings are incorporated into the subsequent analysis.

143 Character analysis

Here we provide new information in the form of a character analysis for features of an

146 admittedly contentious fossil, Eumorphocystis. The focus is primarily on feeding appendages but

147 includes observations from adjacent skeletal anatomy as well. This analysis is based on

148 examination of specimens hitherto unexamined by those who have suggested a sister group

149 relationship to crinoids for this taxon (Sheffield and Sumrall, 2019a; Deline et al., 2020).

150 Accompanying reasoning that strongly supports a position for Eumorphocystis contrary to this

151 earlier work is presented with this analysis. The cases for or against hypotheses of homology,

152 here and in the opposing viewpoint, both depend upon congruency and accepted ontogenetic,

153 morphological, and positional criteria for homology (Patterson, 1988; Freudenstein, 2005).

154 Past criticisms of our conclusions regarding the origins of crinoids (most recently

155 Sheffield and Sumrall, 2019a) cited reliance on what were perceived to be a priori assumptions.

156 It was claimed that our work presupposed reasoning or knowledge proceeding from theoretical

157 deduction. However, accepted theories such as the Extraxial-Axial Theory were developed from

158 empirical observations and theoretical induction, not the other way around (Mooi and David,

159 1997). Our aforementioned methodology is brought to bear on hypotheses of homology in a

160 detailed explication, without coding based solely on superficial resemblances of individual

161 features that do not fully consider information gleaned from other sources, including but not 
162 restricted to the overall relationships of these features one to another. Our approach has, and 163 continues to be, utilization of these explications to code features, and to test these hypotheses of

164 homology in a full phylogenetic analysis. This approach is integral to the uncovering of 165 phylogenetic signal.

166 The same authors criticizing our approach rely on analyses that do not provide detailed

167 delineation of character state parameters, full probing of superficial similarity, or support for 168 why a given transformation series should be a part of a given character or carry phylogenetic 169 signal (Kammer et al., 2013; Sumrall, 2017; Wright, et al., 2017; Deline, et al. 2020; inter alia). 170 Approaches that differ from ours (e.g. Deline et al. 2020) leave uncited available data, or

171 findings that undermine codings they favor (David et al., 2000; Guensburg et al., 2010;

172 Guensburg et al., 2016; Lefebvre et al., 2019; inter alia). We prefer a different way of dealing

173 with echinoderm phylogeny, particularly when working with fossils open to more than one

174 interpretation. As stated in Mooi and David (1997: 306), "The issue of subjectivity versus

175 objectivity is often raised in reference to character analysis, usually with the implication that it is

176 not objective to try to assess the degree to which we can trust phylogenetic signal from certain

177 features. As cladists interested in quality of data as well as quantity, we are resisting the

178 implication that the more we know about our characters, the less objective the study will be."

179 A criticism of our methodology centered on reliance upon differences rather than

180 similarities in our analyses (Wright et al., 2017, p. 831). This oversimplifies our approach and

181 does not fully recognize the strengths of the phylogenetic method itself. Similarities and

182 differences are nested concepts and provide the basis for evaluation of critical issues concerning

183 homoplasy or homology. Commonality at one level of universality will be a difference at

184 another, and our application of the data we have gathered recognize this explicitly. Moreover, 
185 our insistence that certain features should not be considered even comparable or coded under the same character system is not founded on a search for differences. We are attempting to address

187 the more profound problem that past nomenclature has reified concepts of similarity that are

188 either inapplicable or violate the central principle that such analyses should capture phylogenetic

189 signal. Our approach employs nuanced and detailed observations drawn from several sources but 190 does not overtly rely on differences. Our evaluations continue to be founded among long 191 established criteria: conjunction, congruence and similarity, and an intimate knowledge of the 192 material at hand (Patterson, 1988; Freudenstein, 2005).

193 We base our characters and codings on analytical data from combined observations 194 accumulated over a period of decades within the framework of established phylogenetic practice 195 (Guensburg, 2012; Guensburg, et al., 2020), and on empirical observations informed by 196 ontogenetic and anatomical information from a wide variety of sources (partially summarized in 197 Mooi and David, 1998; Mooi et al., 2005; inter alia), including from extant specimens whose 198 anatomy is frequently ignored in the context of what is plausible among fossil forms. Recent 199 workers have appropriately applied new or previously little used methodology to the issue of 200 crinoid phylogeny (Ausich, 2015b; Wright et al., 2017), but such approaches should incorporate 201 information from other well-founded methodologies including those utilized here and in other 202 works (e.g. Guensburg et al., 2016; Guensburg, et al., 2020).

203 Here, we start with observations benefiting from anatomical details furnished by the large 204 Eumorphocystis sample size, improved understanding of earliest crinoid morphology and data 205 from origins of specific body wall regions (Mooi and David, 1997, 2008; David et al., 2000; 206 Guensburg and Sprinkle, 2007, 2009; Guensburg, 2012; Guensburg et al., 2016; Guensburg et 207 al., 2020; inter alia). We begin with the three homologies proposed to link Eumorphocystis to 
208 crinoids (Sheffield and Sumrall, 2019a) and continue with expanded comparative data from

209 feeding appendages and beyond. These ultimately test the number and specific kinds of

210 transformations in a series of hypothetical evolutionary events required to support an exclusive

211 link between Eumorphocystis and the common ancestor of Crinoidea.

212

213 Coeloms. - The central issue and a principal point of departure of the concept that crinoids are

214 sister to Eumorphocystis (Sheffield and Sumrall, 2019a) in this restudy concerns the

215 interpretation of canals associated with feeding appendages. Adding uncertainty to this matter is

216 the scarcity of comparative information for brachiolar and floor plate canals of blastozoans in

217 general (see Sprinkle, 1973; Clausen et al., 2009, for examples). Among early crinoids, these

218 data have only recently been extensively analyzed in a phylogenetic context, although the nature

219 of these canals has long been understood from an anatomical standpoint (Heinzeller and Welsch,

220 1994; and summarized in Guensburg et al., 2020).

221 Present evidence shows that longitudinal feeding appendage canals, otherwise termed

222 median canals (Sprinkle, 1973), exist in a diversity of blastozoans (gogiids, rhipidocystids,

223 rhombiferans, blastoids) (Fay, 1960; Sprinkle, 1973; 1975; Clausen, et al., 2009; Sumrall and

224 Sheffield, 2019a) (Figs 2-4, 6.1-6.4, 6.6, 6.8, 6.9). However, the generally small scales of

225 available material, and the tendency for diagenesis to obscure details with calcitic infilling or

226 eliminate them through moldic preservation that show only plate exteriors, combine to contribute

227 to the scarcity of data. Further, material with attached feeding appendages remains unavailable

228 for many blastozoans, and even ambulacra on thecae are not commonly broken through in such a

229 way that might reveal internal canals. Not surprisingly, no comprehensive study of blastozoan

230 median canals is available, and none is documented for most taxa. Blastozoan median canals 
231 pass through floor plates and their extensions, the brachiolars, presumably to their tips. They are

232 housed within floor plates, and in nearly all known cases, pass between opposing floor plate

233 elements along the appendage mid-line. In one case, canals are encased in uniserial floor plates

234 extending from arms to the theca (Clausen, et al., 2009). Position of canals and the fact that these

235 seem to extend to the oral region suggest they housed nerve branches extending from the

236 circumoral ring. This latter anatomical configuration can be observed among living echinoderms.

237 Previously reported blastozoan canals are circular openings, on the order of $0.1 \mathrm{~mm}^{2}$

238 (using $A=\pi r^{2}$, the area for a circle) or smaller in section. These are housed within floor plates

239 or, in the case of brachiole-bearing blastozoans, brachiolars. The roughly elliptical appendage

240 cavities seen in Eumorphocystis are larger than those of other blastozoans, being approximately

$2411.3 \mathrm{~mm}^{2}$ in section (using $A=\pi \mathrm{ab}$, the area for an ellipse) (Fig. 2.2, but see Fig. 3.6 for much

242 smaller canal). These transition proximally to much smaller, more circular, canals,

243 approximately $0.14 \mathrm{~mm}^{2}$ in section (Figs. 3.2, 3.4-3.6, 4.2, 4.6), on a scale similar to those of

244 other blastozoans. These small proximal canals are often obscured by spar-filling similar in color

245 to adjacent spar-filled plates (Figs. 2.3, 3.4, 4.1). This narrowing occurs at the second to fourth

246 ambulacrals distal to the orals, except in the C-ray where differentiated floor plates skirt the

247 periproct region. In both cases, though, this change takes place not far beyond the thecal wall.

248 Topology in the proximal regions agrees with the most common blastozoan pattern in that canals

249 run along the perradial sutures (ambulacral midline) that form contacts between opposing floor

250 plates. On the theca itself, canals proceed within floor plates just above, but not through, the

251 thecal wall (Figs. 4.2, 4.3). These narrow canals were observed to reach the orals (Fig. 3.5).

252 Opposing floor plate walls each form a hemi-canal or "half-pipe" (Fig. 3.2, 3.5). Larger than 
253 usual more distal canals could have accommodated expanded innervation of appendages

254 supplying the dense array of brachioles.

255 The situation among early crinoids (see Guensburg et al., 2010; Guensburg et al., 2020,

256 for detailed analysis) (Figs. 5, 6.5, 6.7) is not comparable to that of Eumorphocystis or any other

257 blastozoan (see Guensburg et al., 2020, for detailed analysis) (Figs. 6.5, 6.7). Unlike blastozoans,

258 crinoid canals expand into the main body mass at thecal shoulders away from the peristome

259 (Figs. 5.1-5.3). In addition, arms themselves express secondary longitudinal grooves within the

260 adoral brachial canals that extend out the arms. Subsequent evolutionary events led to the

261 submergence of this secondary groove into brachials, thereby transforming what initiated as

262 grooves into intraplate canals. Instances of the enclosed canal condition are known from as early

263 as the Late Ordovician (e.g. Columbicrinus) (Guensburg et al., 2020, Fig. 7) and occur among all

264 living crinoids. These canals house the brachial (also known as the aboral) nerve, part of the

265 subepithelial system sensu Heinzeller and Welsh (1994). Ontogeny of living crinoids

266 recapitulates this change in position of the nerve canal, which was originally only partly

267 submerged into brachials.

268 It is important to note that the derived brachial canal condition in modern crinoids and

269 certain fossils superficially resembles the situation found among blastozoans. In both cases, a

270 canal perforates the primary skeletal support elements of feeding appendages. However,

271 comparative study of the nature and origin of the plate bearing canals using earliest crinoid as

272 well as modern crinoid anatomy reveals fundamentally different housing elements: extraxial

273 brachials in crinoids, axial floor plate and brachiolar canals in blastozoans (Fig. 6). Accordingly,

274 proposed homology of Eumorphocystis feeding structures with those of crinoids becomes more

275 conjectural, since there remains no plausible evidence for somatocoels. The polarity of the 
276 changes above does not rely on a priori reasoning, but on reciprocal illumination of direct

277 observation of conditions that have nothing to do with the nerve canals themselves, and that are

278 congruent with the topology of the same tree that makes sense of these canal character

279 transitions.

280

281 Tripartite pseudo-arms. - See Summary of character analysis findings below for definition of

282 "pseudo-arm". A finding for homologous tripartite feeding appendages assumes this condition

283 arose through the blastozoan Eumorphocystis to be inherited by earliest crinoids. Recently

284 revealed evidence from earliest crinoids does not support such a series of events because the

285 tripartite pattern is not the earliest condition for crinoid arms (Guensburg et al., 2020). Instead, it

286 simply represents an additional state observed among more crownward crinoids, a state not

287 found among the common ancestor of that group. Earliest crinoid arms (Apektocrinus,

288 Titanocrinus, Glenocrinus) are not tripartite because they express lateral fields of platelets

289 extending from the cup along the arms between brachials and floor plates, in one case, all the

290 way to the arm tips (e.g. Titanocrinus) (Guensburg et al., 2020, Figs. 10.5, 10.6).

291

Radials.-Differentiated thecal plates lying at the base of the extraxial feeding appendage

293 series in Eumorphocystis have been interpreted to be homologous with similarly positioned

294 crinoid radials (Sheffield and Sumrall, 2019a). These, like those of crinoids lie at the base of a

295 uniserial, radially positioned plate column, occur at the juncture with the thecal wall, and express

296 a distinct facet articulating with a more distal extraxial plate. The comparison of proposed

297 Eumorphocystis radials fails when a more nuanced attempt to homologize this pattern with that

298 of Early Ordovician crinoids is implemented. In early camerates (Guensburg and Sprinkle, 
299 2003), fixed brachials continue upward from radials in a uniserial series within the body wall.

300 However, in the case of Eumorphocystis, no uniserial body wall plates continue above putative

301 radials (Eumorphocystis backing series below). If the comparison is with cladids, the radial

302 facets should express notches accommodating the passage of coeloms extending outward from

303 the thecal shoulder, yet they do not. There is no opening leading distally into the feeding

304 appendages from the "radials" of Eumorphocystis. Plates extending distally from the proposed

305 Eumorphocystis "radial" confirm this anatomy. The first aboral plate beyond the "radial" of

306 Eumorphocystis lacks an adoral groove. Stated another way, the proposed coelomic canal

307 (above) does not bound either the putative radials or in the first two or three subsequent putative

308 brachials. Furthermore, diplopores are evident in the so-called radials in Eumorphocystis (Fig.

309 2.6), features unlike crinoid respiratory structures.

311 Ambulacral grooves.-Ambulacral grooves of Eumorphocystis are narrow and shallow,

312 approximately only a quarter of the entire arm width. Those of early crinoids are wide and deep,

313 set down within the adoral grooves of brachials, spanning the entire floor plate and arm's width.

314 It is not until more crownward taxa within the Crinoidea that narrower ambulacral grooves are

315 encountered. It is unparsimonious to hypothesize that Eumorphocystis represents the

316 plesiomorphic morphology of the common ancestor of crinoids and blastozoans when the earliest

317 crinoids express dissimilar groove morphology, only to see something similar reappear in

318 crownward crinoids, particularly when an alternative more parsimonious placement of

319 Eumorphocystis exists. 
321 Floor plates.-Like blastozoans in general, Eumorphocystis floor plates are massive, blocky

322 elements lacking podial pores. They have large exposed surfaces, both on the theca, and along

323 pseudo-arms, where they form the exposed tops and sides of arms. In nearly all blastozoans,

324 pseudo-arms do not include extraxial elements and form the entire aboral appendage surface.

325 Each Eumorphocystis floor plate bears a facet that facilitated infolding of an attached brachiole

326 toward the peristome (Figs. 2.1, 2.4). The initial floor plate just beyond the orals is distinctly

327 elongate. By contrast, early crinoid floor plates are delicate, largely internal, slat-like elements,

328 with shared podial pores between sequential elements (Guensburg and Sprinkle, 2001, 2009;

329 Guensburg et al., 2020). Arm support in this case is provided by brachials, the extraxial elements

330 that form the aboral surface of the arm (Fig. 5). Although one could envision that thin crinoid

331 floor plates were highly modified from the block-like versions seen in Eumorphocystis, the lack

332 of podial pores makes this an unparsimonious proposition given the frequency of pores in other

333 echinoderms (e.g. edrioasteroid-like forms, certain edrioasteroids) that have hitherto not at all

334 been at all associated with blastozoans. In other words, extensive convergent evolution of podial

335 pores would have to be proposed in the face of strong similarities among them, as well as

336 broadly accepted phylogenetic evidence supporting blastozoan monophyly to the exclusion of all

337 other major echinoderm clades (Guensburg et al., 2016; Guensburg et al., 2020).

339 Pinnules and brachioles. - First, it should be recognized that blastozoan brachioles and crinoid

340 pinnules, although superficially similar, are only partly homologous structures in which

341 respective nonhomologous portions indicate significantly different soft tissue anatomies. Both

342 crinoids and blastozoans express cover plates, axial constructs over the ambulacra. However,

343 primary supporting skeletal structures are non-homologous. Blastozoan brachiolars are axial 
344 extensions from ambulacral floor plates, crinoid pinnulars are extraxial extensions from the 345 thecal body wall beyond the ambulacra (Mooi and David, 1997, 1998). Brachioles were a

346 diagnostic blastozoan apomorphy from the onset of their origination during the Early Cambrian

347 (Sprinkle, 1973). On the other hand, all known earliest crinoids were apinnulate (Guensburg,

348 2012; Guensburg et al., 2020). It is widely agreed among crinoid workers that pinnules evolved

349 independently at different times among camerate, cladid, and disparid crinoids (Ausich, 1988;

350 Sheffield and Sumrall, 2019a). Modern crinoid anatomy shows the same basic anatomy in arms

351 and pinnules including the presence of left and right somatocoel extensions (Mooi and David,

352 1997, 1998). There is no evidence that would support a different conclusion in the various fossil

353 crinoids.

354 Thecal and feeding appendage floor plates of Eumorphocystis each bear a uniserial

355 brachiole (Fig. 2.1). These formed a dense filtration fan superficially much like pinnulate crinoid

356 arms (Parsley, 1982) (Fig. 1). The suggestion that a Eumorphocystis-like ancestor first lost

357 brachioles, then later evolved pinnules, after crinoids themselves had evolved (Sheffield and

358 Sumrall, 2019a), requires loss of brachioles in a pre-crinoid phase, followed by development of

359 pinnules after the origination of crinoids. The added complexity for this posited sequence of

360 events undermines supposed homology between the feeding appendages of Eumorphocystis and

361 the arms of any of the pinnulate crinoids, whether pinnules evolved more than once or not.

362

363 Cover plates.-Arm cover plates of earliest crinoid are arranged in a two-tiered pattern

364 (Guensburg et al., 2020). Eumorphocystis appendage cover plates are arranged in a single-tiered

365 alternating biseries, each with a transverse keel running laterally or orthogonal to the longitudinal

366 axis of the appendage (Fig. 2.1). This biseries pattern occurs consistently among early blastozoan 
367 brachioles (e.g. the Cambrian imbricates such as lepidocystids, and gogiids) (Sprinkle, 1973).

368 Ambulacral and oral surface cover plating can be more complex, an irregular multi-series,

369 usually a biseries, within a single tier. Derivation of a two-tiered early crinoid-type cover plate

370 pattern from this single blastozoan biseries necessitates novel development of additional plates in

371 stories. Accordingly, this option is not parsimonious given that complex cover plate

372 configurations from which an incipient two-tiered early crinoid pattern potentially originated

373 were available among Cambrian edrioasteroid-like (Smith and Jell, 1990, Fig. 4a; Zhao et al.,

374 2010, Fig. 6.7, for instance) and Early Ordovician edrioasterid edrioasteroid (Sprinkle and

375 Sumrall, 2015; Zamora et al., 2015, et al.) echinoderms (see Guensburg et al, 2020).

376

377 Eumorphocystis backing series.-Exterior views of the uniserial backing plates of

378 Eumorphocystis appear crinoid-like. However, their interiors (oral surfaces) do not. The adoral

379 groove of early crinoids is much larger and deeper than the groove forming the bottom of the 380 pseudo-arm canal in Eumorphocystis and in crinoids, it bears a secondary groove (Figs. 6.4, 6.5

381 and 6.7).

382

383 Pseudo-arm buttressing.-Eumorphocystis pseudo-arms are buttressed by a solid wedge of 384 plates underlying floor plates. Additions to this plate wedge are inserted below floor plates 385 during ontogeny. Crinoid arms expand approaching the theca and this expanded region is hollow, 386 the expanding space bounded aborally by brachials and thin lateral plate fields that lie just 387 aborally to the floor plates (Figs. 5, 6.5, 6.7). No known intermediaries link these disparate 388 morphologies. 
390

391

392

393

394

395

396

397

398

399

400

401

402

403

404

405

406

407

408

409

410

411

Summary of character analysis findings._- Detailed anatomical analysis does not support somatocoelar, radial, or brachial homologies linking Eumorphocystis with crinoids. To signify these essential differences between the feeding appendages in blastozoans, and the "true arms" of crinoids, we refer to those seen in Eumorphocystis and other blastozoans with similar configurations as "pseudo-arms" (referred to as exothecal ambulacra by Sprinkle, et al., 2011).

Thecal plate and respiratory systems, and stem/stalk morphology concur with these findings (Guensburg and Sprinkle, 2007; Guensburg et al., 2010; Guensburg et al., 2016).

\section{Testing the claim of crinoid sister-group status for Eumorphocystis}

The finding for a sister group relationship of Eumorphocystis, a blastozoan, and crinoids was accompanied by a phylogenetic analysis (Shefffield and Sumrall, 2019a). A more recent study that used Eumorphocystis and other taxa from this study, recovered different results - that crinoids arose independently from pentaradiate echinoderms apart from blastozoans (Guensburg et al., 2020). The present analysis builds upon this latter study, with a primary goal to elucidate further the phylogenetic position of blastozoans, and in particular Eumorphocystis within this context. The total taxon list from Guensburg et al. (2020) is expanded from 21 to 25 (Table 2), and the character list increased from 34 to 39. Essentially the entire range of taxa used to support a Eumorphocystis sister-group status with crinoids was implemented (Sheffield and Sumrall, 2019a). Added taxa include a Middle Ordovician hemicosmitid, a Silurian coronoid blastozoan, and a diplobathrid crinoid. Furthermore, we included the Early Ordovician rhodocrinitid Proxenocrinus, among the earliest-known pinnulate crinoids. However, Cambrian and Early 
412 Ordovician taxa continue to remain in the overall taxon list in order to code for characters found 413 in the earliest members of the clades to which they belong.

414

1. Left and right somatocoels: left and right somatocoels underlie ambulacra along their entire length (0); somatocoels restricted to thecal interior (1). State (0) includes those arm-bearing taxa with cavities extending uninterrupted from thecal shoulders. This trait, from a practical standpoint, highlights a key difference in feeding appendage construction. State (1) includes cases where cavities do not extend uninterrupted from the theca, such as Eumorphocystis. Here, this relationship is considered similar to that of paracrinoids where such a cavity has been referred to as a lumen (Parsley and Mintz, 1975).

2. Podial pores or basins: present (0); absent (1). Determining the existence of podial pores or podial basins is crucial to assessing relationships among early crinoids, as well as with other early echinoderm groups. The fossils can be difficult to interpret where weathering and diagenesis obscure plate boundaries such as in the fossils treated here (see Taphonomy and Preparation above). The best supported interpretation, obtained by coated, submersed, and dry images, is that there are at least podial basins if not actual pores in basins that extend to water vascular elements inside the coelom, internal to the floor plates. Although not documented in later Paleozoic crinoids, these structures can be seen in Aethocrinus, Athenacrinus, Apektocrinus, Titanocrinus, and possibly Glenocrinus (Guensburg et al., 2020, Figs. 4.4, 4,6, 10.3, 10.4).

433 3. Floor plates on the theca: floor plates short, relatively wide (0); long, relatively narrow 434 (1). This trait does not code for appendage morphology. 
4. Floor plates in appendages: plates thin, slat-like, not providing primary appendage supports (0); thick, blocky, forming primary appendage skeletal supports (1).

5. Ambulacral cover plates: arranged in lateral and medial tiers (0); in a single biseries of lateral plates (medial tier not expressed) (1). Medial and lateral tiers were previously referred to as primary and secondary cover plates (Paul and Smith, 1984). Single cover plate tiers can be arranged in an alternating double or other multiple series, but plates form two distinct levels (Guensburg et al., 2020). Patterns can be difficult to interpret in plesiomorphic Cambrian forms where plates are more irregular, but an incipient two-tiered pattern can be discerned (Smith and Jell, 1990; Zhao et al., 2010).

6. Medial cover plates: overlapping elements diminishing in size as they arch over the perradial suture (0); an alternating double biseries (1). This character requires medial cover plates and is scored as inapplicable for those taxa lacking medial cover plates.

\section{Hinging of thecal (non-appendage) cover plates: hinged, capable of opening and} closing (0); fixed, forming closed ambulacral tunnels (1).

8. Axial orals: absent (0); expressed as differentiated interradial elements surrounding the peristome in all interrays and forming junctions of ambulacra (1). Axial orals are not regarded as homologous with similarly positioned, extraxial, oral-like plates such as those of modern crinoids or of Hybocrinus nitidus and Carabocrinus treadwelli (see Guensburg et al, 2016, for supporting argumentation). Further, earliest hybocrinids lack orals entirely, suggesting acquisition independent from (and therefore not homologous with) the orals seen in blastozoans such as Eumorphocystis (Guensburg and Sprinkle, 2017). The plating of the oral region of Stromatocystites pentangularis includes oral- 
like plating in $\mathrm{AB}$ and $\mathrm{EA}$ interrays. This latter state is autapomorphic among the taxa studied and is omitted from the analysis.

9. Brachioles: absent (0); present (1). Brachioles are entirely axial in construction whether uniserial or biserial, their primary support structures always arising from (axial) floor plates, or representing extensions of those floor plates beyond the perforate extraxial region.

10. Fixed rays: contacted entirely by non-standardized plating (0); contacted by standardized circlet(s) in part or entirely (1). Fixed rays are the uniserial series in continuity with the primary appendage support plate series. This character is inapplicable for those taxa lacking true arms sensu David and Mooi (1999:2) and David et al. (2000: 354) thin, often corrugated, stereom at plate corners.

471 four plates (3); single fused element (4); three plates (5). State (1) consists of a ring of larger thecal plates above a narrower, pinched, pedunculate zone.

\section{Dorsal cup: conical (0); bowl-shaped (1). The term "dorsal cup" requires left and right}

477 14. CD interradius elevation: not expressed except for periproct or anal cone (0); long cylindrical sac (1). somatocoels extending from the thecal shoulders (character 1 above). This character is inapplicable for those taxa lacking true arms according to David and Mooi (1999: 92) and David et al. (2000: 354) (see character 19).

15. CD interradial gap plate: present (0); absent (1). This character requires the presence of true arms. State $(0)$ requires extension of the $\mathrm{CD}$ interray gap to the stem/stalk, that is, 
they interrupt the cup base circlet. Gap plates are relatively small and are inserted between an otherwise more or less regular thecal base circlet (character 12).

16. True basals: absent (0); expressed as a differentiated mid-cup circlet between infrabasals, if present, and true radials (1). State (1) requires the presence of true arms and is therefore marked as not applicable in cases when true arms are absent (see character 19). refers to a subsidiary channel along the interior aboral surface of the presumed coelomic channels in feeding appendages and extending from the theca. This groove could have housed the brachial nerve.

18. True radials: absent (0), present (1). A true radial represents the proximalmost extraxial plate of a true arm ray series. These support free arms at least early in ontogeny. This character requires the presence of true arms and is therefore marked inapplicable in cases where true arms are absent. Eumorphocystis expresses extraxial elements superficially similar to true radials of the type seen in derived crinoids where radials form the cup top. Unlike crinoids, the Eumorphocystis plates are not located at the cup top (see Sheffield and Sumrall, 2019a) and facets have no coelomic notches or other evidence of any communication to the thecal interior. true arms: absent (0), present (1)

20. True arm branching pattern: true arms atomous, non-branching (0); isotomously branching (1); endotomously branching (2). This character is scored inapplicable for taxa lacking true arms and refers to distalmost branching pattern. 
21. Brachials: absent (0); brachials present (1). Brachials, when expressed, constitute primary skeletal supports for the feeding appendages. This character requires true arms and is scored inapplicable for taxa lacking true arms. Eumorphocystis expresses uniserial backing plates superficially resembling brachials, but these do not form primary appendage supports and do not contain a through-going coelomic canal.

22. Extraxial laterals: present, accompanying extended thecal wall out arms (0); absent. Extraxial laterals, when present, occupy aboral arm surfaces aside from brachials. State (0) requires true arms and is scored inapplicable for taxa lacking true arms.

23. Platelet webs at branchings: present (0); absent (1). These plate fields are most parsimoniously regarded as extensions of extraxial lateral plating (see character 22). This character requires true arms and is scored inapplicable for taxa lacking true arms. 24. Fixed brachials: present (0); absent (1). Fixed brachials are ray plates that extend aborally from true radials and are embedded in the cup; they articulate laterally with interradial plates. This character requires true arms and is scored inapplicable for taxa lacking true arms.

25. Cup-like fixed brachials: three or more in all rays (0); none to two in all rays (1); cuplike fixed brachials in C or E rays only (2). Cuplike indicates plates embedded in the cup with margins flush with adjacent cup plates, much like radials. This character requires true arms and is therefore scored inapplicable for taxa lacking true arms. Polarity is established by the known crinoid record.

26. One or more brachial pairs in lateral union above branchings: present (0); absent, not paired above branchings (1). This character requires true arms and is therefore scored inapplicable for taxa lacking true arms. 
27. Interradial plate fields separating multiple fixed primibrachials: much wider than fixed rays (0); interradial fields not as wide as fixed rays or absent (1); interradial plate fields absent (2). Width is assessed across the widest portion of the field and compared with the widest fixed brachial. This character requires true arms and is therefore scored inapplicable for taxa lacking true arms.

28. $C D$ interradius: $\mathrm{CD}$ interradius extending downward to the base of the thecal cavity (0); ending at true radials (1). State (0) indicates the radial circlet is interrupted across the CD interradius, and state (1) indicates radials are contiguous below the CD interradius. This character requires true arms and is therefore scored inapplicable for taxa lacking true arms.

29. Radianal(s) and anal X plates: absent (0); present (1). State (1) consists of differentiated plates occupying the space below and to the left of a "raised" C radial. The radianal can be absent in later more derived taxa, but not those treated here. States (0) and (1) require presence of true arms and are therefore scored as not applicable for those forms lacking them.

30. Anibrachial plate: absent (0), or present (1). This character requires true arms and is therefore scored inapplicable for those taxa lacking true arms. anisotropic, imbricate, plated peduncle (1); irregularly tessellated peduncle with pinched demarcation at base of theca (2); monomeric (holomeric) stem (3); pentameric stalk (4). Carabocrinus treadwelli and Hybocrinus nitidus pentameres are inconspicuous (see Sprinkle, 1982a, Figs. 45D, 46H). Note: The presence of a stem has traditionally been used as a key feature linking blastozoans and crinoids, together these 
comprising the pelmatozoans. Stems are now known among edrioasteroids as well as

550

551

552

553

554

555

556

557

558

559

560

561

562

563

564

565

566

567

568

569

570

571

blastozoans and crinoids (Guensburg and Sprinkle, 2007; Guensburg et al., 2010).

Therefore, it is not unparsimonious to assume that stems/stalks evolved more than once.

Here we identify types of stems where, at least among treated taxa, a pattern emerges

whereby blastozoan and earliest crinoid stems are distinguishable. This approach does not

apply to later, more crownward taxa where homoplasy presumably results in more similar constructs.

32. Stalk/stem lumen: absent (0); round or irregular trilobate in cross section (1); pentalobate in cross section (2). This character requires a stalk or a stem and scored as not applicable for those forms lacking a meric stalk/stem.

33. Ray length on theca: long, approaching the perforate/imperforate boundary in extraxial body wall (0); short, restricted to the region around peristome and not approaching boundary between perforate and imperforate extraxial body wall (1).

34. Extraxial “orals”: absent (0); present (1). The interradial circlet bordering the peristome of Hybocrinus nitidus and Carabocrinus treadwelli is considered extraxial and homologous among these and a few other cyathocrinine crinoids (Porocrinus, Palaeocrinus, inter alia); these are all characterized by flat tegmens of few plates and with a hydropore within a single posterior "oral".

35. Gonopore: undifferentiated from hydropore (0), a slit-like pore apart from hyropore (1). State (1) requires an opening in the CD interray separate from the hydropore.

36. Hydropore or combined hydropore-gonopore: an interplate pore bordered by small platelets (0); a slit shared across two plates separate from hydropore (1); an intraplate pore (2), subcircular pore shared across two plates (3). 
37. Pinnules: absent (0), present (1). This character requires true arms. Pinnules are

573

574

575

576

577

578

579

580

581

582

583

584

585

586

587

588

589

590

591

592

593

594 supported by extraxial elements, and are constructed nearly identically to true arms, including containment of coeloms characteristic of arms. Pinnules are not homologous with brachioles, which can nonetheless superficially resemble pinnules.

38. Ray branching in dorsal cup: no branching in dorsal cup (0); branching from fixed brachial on the theca (1).

39. Uniserial posterior plate column: absent (0); present (1).

These 39 characters were assembled for scoring using Mesquite Version 3.2 (build 801), and the nexus file run on PAUP 4.0a (build 167) for Macintosh. All characters were unordered and unweighted; one character was parsimony uninformative (Table 3). The analysis employed the branch and bound algorithm, consensus trees were computed, and a bootsrap analysis of 10,000 replicates was run using a fast heuristic search.

\section{Results of the phylogenetic analysis}

We are acutely aware that merely piling up evidence that crinoids are different from blastozoans is insufficient to falsify the idea that crinoids are derived from within the blastozoan clade, let alone the diploporites, which appear to be non-monophyletic in any case (Sheffield and Sumrall, 2019b). However, unlike previous analyses, we allow for the strong likelihood that morphologies in feeding and other structures are merely superficially similar in blastozoans and crinoids, and lack phylogenetic signal due to homoplasy. For us, the key to uncovering this homoplasy is detailed study of the fossils themselves, details, in addition to broader comparisons with early taxa of both crinoid and blastozoan clades in which these features have very different 
595 expressions from those in more crownward forms. Even if it could be shown that

596 Eumorphocystis was a sister to crinoids, this is insufficient to place Crinoidea within any more

597 inclusive blastozoan taxon, without trying to explain why crinoids lack so many of the

598 apomorphies of blastozoans, as also discussed in Guensburg et al. (2020).

599

Nevertheless, our study of material adequate to close data gaps evident in the Sheffield

600 and Sumrall (2019) analysis are not consistent with the suggestion that Eumorphocystis is

601 relevant to the question of crinoid relationship with blastozoans. The latter is a monophyletic

602 assemblage exclusive of the Crinoidea. No blastozoans, let alone the highly derived

603 Eumorphocystis, are more closely related to crinoids than they are to other blastozoans (see

604 Sheffield and Sumrall, 2019b, for a recent treatment of diploporites, in which Eumorphocystis

605 has traditionally been included).

606

Results generally mirror those of Guensburg et al., 2020, and even with additional taxa,

607 and are not surprising given the disparate morphological interpretations relative to those of the

608 opposing view (Sheffield and Sumrall, 2019a). This phylogenetic analysis recovered 660 most

609 parsimonious trees of length 75 , consistency index (CI) of 0.675 , retention index (RI) of 0.845 ,

610 rescaled consistency index (RC) of 0.594 , and homoplasy index (HI) of 0.307 . Strict $50 \%$ and

611 majority rule consensus trees are shown in Figure 7, along with the results of the bootstrap

612 analysis. Eumorphocystis branches high in the blastozoan lineage, distantly related to crinoids,

613 which are place closer to the earliest pentaradiate echinoderm branch. Blastozoan history

614 begins during the Early Cambrian, separate from crinoids.

615 Crinoids are first recognized during the Early Ordovician (Guensburg and Sprinkle,

6162003,2009 , inter alia). Arm morphology in both modern and fossil crinoids indicates an origin

617 from non-blastozoan pentaradiate echinoderms (David and Mooi, 1999; Mooi et al., 2000; 
618 Guensburg and Sprinkle, 2007; Guensburg et al., 2010; Guensburg et al., 2012; Guensburg et 619 al., 2016; Guensburg et al., 2020). Incorporation of the camerate crinoid taxa Proxenocrinus 620 and Gaurocrinus in the expanded dataset here (characters 35-39) produced a different overall

621 crinoid topology from an earlier iteration (Guensburg et al., 2020) with disparid and traditional

622 camerate clades as sister taxa. This result contrasts with recent findings (Ausich et al., 2015a;

623 Ausich et al., 2015b; Ausich et al., 2020; and Ausich et al., 2020) but is essentially that

624 suggested by another author (Gahn, 2015). The inclusion of pinnulation, character 37 , is

625 interesting because it appears to provide phylogenetic signal only early in crinoid history. This

626 character eventually occurs in disparids and cladids as well as camerates, but the current record

627 indicates this feature evolved first among camerates, during the Late Floian. Pinnules are not

628 known not among cladids and disparids until the Late Ordovician.

629

630 Acknowledgements

631 David Quednau ably assisted in the preparation of figures. We gratefully acknowledge 632 the loan of Eumorphocystis material from the Sam Noble Museum, Universiy of Oklahoma. C. 633 Paul and an anonymous reviewer provided thoughtful and constructive reviews.

635 References

636 Ausich, W.I., 1986, The crinoids of the Al Rose Formation (Early Ordovician, Inyo County, 637 California, U.S.A.): Alcheringa, v. 10, p. 217-224.

638 Ausich, W.I., 1988, Evolutionary convergence and parallelism in crinoid calyx design: Journal of 639 Paleontology, v. 62, p. 906-916. 
640

641

642

643

644

645

646

647

648

649

650

651

652

653

654

655

656

657

658

659

660

661

Ausich, W.I., 2018, Morphological paradox of disparid crinoids (Echinodermata): phylogenetic analysis of a Paleozoic clade: Swiss Journal of Palaeontology, v. 137, p. 159-176. https//doi.org/10.1007/s13358-0180147-z

Ausich, W.I., Kammer, T.W., Wright, D., Cole, S., Peters, M., and Rhenberg, E., 2015a, Toward a phylogenetic classification of the Crinoidea (Echinodermata): pages 29-32, In Zamora, S., and Romano, I. (eds.). Progress in Echinoderm Paleobiology. Instituto Geológico y Minero de España Cuaderno del Museo Geominero, 19, p. 29-32.

Ausich, W.I., Kammer, T.W., Rhenberg, E.C., and Wright, D.F., 2015b, Early phylogeny of crinoids within the pelmatozoan clade: Palaeontology, v. 58, p. 937-952.

Ausich, W.I., Wright, D.F., Cole, S.R., and Sevastopulo, G.D., 2020, Homology of posterior interrays in crinoids: a review and new perspectives from phylogenetics, the fossil record, and development: Palaeontology, v. 2020, p. 1-21. https://doi.org/10.1111/pala.12475.

Blakey, D. Deep Time Maps--maps of ancient Earth: https://deeptimemaps.com/. Accessed September 10, 2018.

Branson, E.B. and Peck, R.E., 1940, A new cystoid from the Ordovician of Oklahoma: Journal of Paleontology, v. 14, p. 89-92.

Breimer, A., 1978, General morphology, Recent crinoids: in Moore, R.C. and Teichert, C. (eds.) Treatise on Invertebrate Paleontology, Part T, Echinodermata 2(1). Geological Society of America Boulder and University of Kansas Press, Lawrence, p. T9-T50.

Callaway, C., 1877, On a new area of Upper Cambrian rocks in South Shropshire, with a description of new fauna: Quarterly Journal of the Geological Society of London, v. 33, p. $652-672$. 
662 Cole, S.R., 2017, Phylogeny and morphologic evolution of the Ordovician Camerata (Class

663

664

665

666

667

668

669

670

671

672

673

674

675

676

677

678

679

680

681

682
Crinoidea, Phylum Echinodermata): Journal of Paleontology, v. 91, special Issue 4, p. 815-828.

Clausen, S., Jell, P.A., Legrain, X., and Smith, A.B., 2009: Pelmatozoan arms from the Middle Cambrian of Australia: Bridging the gaps between brachioles and brachials: Lethaia, v. $43,432-440$.

Conrad, T.A., 1842, Descriptions of new species of organic remains belonging to the Silurian Devonian, and Carboniferous Systems of the U.S.: Philadelphia Academy of Natural Sciences, Journal (old series), v. 8, p. 235-280.

David, B., and Mooi, R., 1999, Comprendre les échinodermes: la contribution du modèle extraxial-axial: Bulletin de la Société Géologique de France, v. 170, p. 91-101.

David, B., Lefebvre, B., Mooi, R., and Parsley, R., 2000, Are homalozoans echinoderms? An answer from the extraxial-axial theory: Paleobiology, v. 26, p. 529-555.

Deline, B., Thompson, J.R., Smith, N.S., Zamora, S., Rahman, I.A., Sheffield, S., Ausich, W.I., Kammer, T.W., and Sumrall, C.D., 2020, Evolution and development at the origin of a phylum: Current Biology, doi:10.1016/j.cub.2020.02.054.

Derstler, K., Guensburg, T.E., Blake, D.B., and Sprinkle, J., 2018, Arms in Camptostroma, an archaic pentaradiate echinoderm: Geological Society of America Abstracts with Programs, v. 50: doi: 10.1130/abs/2018AM-324634.

Durham, J.W., 1966, Camptostroma, an Early Cambrian supposed scyphozoan referable to Echinodermata: Journal of Paleontology, v. 40, p. 1216-1220. 
683 Durham, J.W., 1967, Camptostromatoids: in Moore, R.C. (ed.) Treatise on InvertebratePaleontology, Part S Echinodermata 1(2). Geological Society of America and the University of Kansas Press, Lawrence, p. S627-S631.

686

687

688

689

690

691

692

693

694

695

696

697

698

699

700

701

702

703

704 248.

Foerste, A.F., 1938, Echinodermata: in Resser, C.E and Howell, B.F. (eds.), Lower Cambrian Olenellus Zone of the Appalachians: Geological Society of America Bulletin, v. 49, p. $212-213$

Freudenstein, J.V., 2005, Characters, states, and homology: Systematic Biology, v. 54, p. 965973.

Geissman, J.W., Bowring, S.A., and Babcock, L.E., compilers, 2018, Geological Time Scale, v. 5.0: Geological Society of America, https://doi.org/10.1130/2018. Accessed in January $17,2019$.

Guensburg, T.E., 2012, Phylogenetic implications of the oldest crinoids: Journal of Paleontology, v. 86, p. 455-461.

Guensburg, T.E., Blake, D.B., Sprinkle, J., and Mooi, R., 2016, Crinoid ancestry without blastozoans: Acta Palaeontologica Polonica, v. 61, p. 253-266.

Guensburg, T.E., Mooi, R., Sprinkle, J., David, B., and Lefebvre, B., 2010, Pelmatozoan arms from the mid-Cambrian of Australia: bridging the gap between brachioles and arms? Comment: there is no bridge: Lethaia, v. 43, p. 432-440.

Guensburg, T.E. and Sprinkle, J. 2001. Earliest crinoids: new evidence for the origin of the dominant Paleozoic echinoderms: Geology, v. 29, p. 131-134. 
705

706

707

708

709

710

711

712

713

714

715

716

717

718

719

720

721

722

723

724

725

726

727

Guensburg, T.E. and Sprinkle, J., 2003, The oldest known crinoids (Early Ordovician, Utah), and a new crinoid plate homology system: Bulletins of American Paleontology, 364: p. 143.

Guensburg, T.E. and Sprinkle, J., 2007, Phylogenetic implications of the Protocrinoidea: Blastozoans are not ancestral to crinoids: Annales de Paléontologie, v. 93, p. 277-290.

Guensburg, T.E., and Sprinkle, J., 2009, Solving the mystery of crinoid ancestry: New fossil evidence of arm origin and development: Journal of Paleontology, v. 83, p. 350-364.

Guensburg, T.E., and Sprinkle, J., 2017, New evidence of early hybocrinid tegmens; Phylogenetic implications: Geological Society of America Abstracts with Programs, Paper number 49-2.

Guensburg, T.E., Sprinkle, J., Mooi, R., David, B., Lefebvre, B., and Derstler, K. 2020. Athenacrinus n. gen. and other early echinoderm taxa inform crinoid origin and arm evolution: Journal of Paleontology, v. 94, p. 311-333.

Hall, J., 1866, Descriptions of new species of Crinoidea and other fossils from the lower Silurian strata principally of the Hudson-River Group (a note on it only): New York State Cabinet, Natural History, 20 ${ }^{\text {th }}$ Annual Report, p. 304.

Heinzeller, T. and Welsch, U., 1994, Crinoidea: in Harrison, F.W. and Chia, F-S. (eds.), Microscopic Anatomy of the Invertebrates, Vol. 14, Echinodermata. Wiley-Liss Inc., New York, p. 9-148.

Hyman, L., 1955, The Invertebrates, Volume 4, Echinodermata: McGraw-Hill, New York, p. 1761.

Jaekel, O., 1899, Stemmesgeschichte der Pelmatozoen, 1 Thecoidea und Cystoidea: P. 1-442, Julius Springer, Berlin. 
728 Jaekel, O., 1901, Über Carpoideen, eine neue Klasse von Pelmatozoen: Zeitschrift der Deutschen 729 Geologischen Gesellschaft, v. 52, p. 661-677.

730 Kammer, T.W., Sumrall, C.D., Zamora, S., Ausich, W.I., and Deline, B., 2013, Oral region 731 homologies in Paleozoic crinoids and other plesiomorphic pentaradial echinoderms:

732 PLoS ONE, vol. 8, p. 1-16. (doi: 10.1371/journal.pone.0077989)

733 Kolata, D.R., 1982, Camerates: in Sprinkle, J. (ed.) Echinoderm faunas from the Bromide 734 Formation (Middle Ordovician) of Oklahoma: The University of Kansas Paleontological 735 Contributions, Monographs v. 1, p. 170-205.

736 Mooi, R., and David, B.,1997, Skeletal homologies of echinoderms: The Paleontological Society 737 Papers, v. 3, p. 305-335.

738 Mooi, R., and David, B., 1998, Evolution within a bizarre phylum: homologies of the first 739 echinoderms: American Zoologist, v. 38, p. 965-974.

740 Mooi, R. and David, B., 2000, What a new model of skeletal homologies tells us about asteroid 741 evolution: American Zoologist, v. 40, p. 326-339.

742 Mooi, R., David, B., and Wray, G., 2005, Arrays in rays: terminal addition in echinoderms and 743 its correlation with gene expression: Evolution and Development, v. 7, p. 542-555.

744 Parsley, R.D., 1982, Eumorphocystis: in Sprinkle, J. (ed.) Echinoderm Faunas from the Bromide 745 Formation (Middle Ordovician) of Oklahoma: University of Kansas Paleontological 746 Contributions, Monograph 1, p. 180-188.

747 Paul, C.R.C., 1968, Macrocystella Callaway, the earliest glyptocystitid cystoid: Palaeontology, 748 v.11, p. $580-600$.

749 Patterson, C., 1988, Homology in classical and molecular biology: Molecular Biology and $750 \quad$ Evolution, v. 5, p. 603-625. 
751 Paul, C.R.C. and Smith, A.B., 1984, The early radiation and phylogeny of echinoderms:

752 Biological Reviews, v. 59, p. 443-481.

753 Pompeckj, J.F., 1896, Die Fauna des Cambrium von Tejrovic und Skrej in Böhmen: Jahrbuch 754 der kaiserlich-königlichen geologischen Reichsanstalt, v. 45, p. 495-614.

755 Robinson, R.A., 1965, Middle Cambrian eocrinoids from western North America: Journal of 756 Paleontology, v. 39, p. 355-364.

757 Roux, M., and Lambert, P., 2011, Two new species of stalked crinoids from the northeastern 758 759 760

761

762

763

764

765

766

767

768 Pacific in the genera Gephyrocrinus and Ptilocrinus (Echinodermata, Crinoidea, Hyocrinoidae). Effects of ontogeny and variability on hyocrinid taxonomy: Zootaxa, v. 2825, p. $1-54$.

Ruedemann, R., 1933, Camptostroma, a Lower Cambrian floating hydrozoan: Proceedings of the United States National Museum, v. 82, p. 1-13.

Sheffield, S.L., and Sumrall, C.D., 2019a, A re-interpretation of the ambulacral system of Eumorphocystis (Blastozoa, Echinodermata) and its bearing on the evolution of early crinoids: Palaeontology, v. 62, p. 1-11 doi: 10.1111/pala.12396.

Sheffield, S.L. and Sumrall, C.D., 2019b, The phylogeny of the Diploporita: a polyphyletic assemblage of blastozoan echinoderms: Journal of Paleontology, online, https://doi.org/10.1017/jpa.2019.2, 13 pages.

769 Sinclair, G.W., 1945, Some Ordovician echinoderms from Oklahoma: American Midland $770 \quad$ Naturalist, v. 34, p. 707-716.

771 Smith, A.B. and Jell, P.A., 1990, Cambrian edrioasteroids from Australia and the origin of starfishes: Memoirs of the Queensland Museum, v. 28, p. 715-778. 
773 Sprinkle, J., 1973, Morphology and evolution of blastozoan echinoderms: Special Publications, 774 Museum of Comparative Zoology, Harvard University, Cambridge, p. 1-283.

775 Sprinkle, J., 1982a, Hybocrinus: in Sprinkle, J. (ed.) Echinoderm Faunas from the Bromide

776 Formation (Middle Ordovician) of Oklahoma: The University of Kansas Paleontological

777 Contributions, Monograph 1, p. 119-128.

778 Sprinkle, J., 1982b, Large-calyx cladid inadunates: in Sprinkle, J. (ed.), Echinoderm Faunas from 779 the Bromide Formation (Middle Ordovician) of Oklahoma: University of Kansas 780 Paleontological Contributions, Monographs v. 1, p. 145-169.

781 Sprinkle, J., 1985, New edrioasteroid from the Middle Cambrian of western Utah: The 782

783

784

785

786

787

788

789

790

791

792

793

794 795

University of Kansas Paleontological Contributions, Paper 116, p. 1-4.

Sprinkle, J., Parsley, R.L., Zhao, Y., and Peng, J. 2011, Revision of lyracystid eocrinoids from the Middle Cambrian of South China and western Laurentia: Journal of Paleontology, v. 85 , p. $250-255$.

Sprinkle, J. and Sumrall, C.D., 2015, New edrioasterine and asterocystitid (Echinodermata: Edrioasteroidea) from the Ninemile Shale, central Nevada: Journal of Paleontology, v.89, p. 1-7.

Strimple, H.L. and McGinnis, M.R., 1972, A new camerate crinoid from the Al Rose Formation, Lower Ordovician of California: Journal of Paleontology, v. 46, p. 72-74.

Sumrall, C.D. and Waters, J., 2012, Universal elemental homology in glyptocystitoids, hemicosmitoids, coronoids, and blastoids: steps toward phylogenetic reconstruction in derived Blastozoa: Journal of Paleontology, v. 86, p. 956-972.

Sumrall, C.D. 2017, New insights concerning homology of the oral region and ambulacral system plating of pentaradial echinoderms: Journal of Paleontology, v. 91, p. 604-617. 
796

797

798

799

800

801

802

803

804

805

806

807

808

809

810

811

812

813

814

815

816

Swofford, D.L., 2003, PAUP*, Phylogenetic Analysis Using Parsimony (*and Other Methods), Version 4: Sinauer Associates, Sunderland, Massachusetts.

Wright, D.F., Ausich, W.I., Cole, S.R., Peter, M.E., and Rhenberg, E.C., 2017, Phylogenetic taxonomy and classification of the Crinoidea (Echinodermata): Journal of Paleontology, v. 91, p. $829-846$.

Ubaghs, G., 1963, Rhopalocystis destombesi n. g., n. sp., éocrinoïde de l'Ordovicien inférieur (Trémadocien supérieur) du Sud marocain: Notes et Mémoires du Service géologique du Maroc, v. 172, p. 25-45.

Ubaghs, G., 1967a, Eocrinoidea: in Moore, R.C. (ed.), Treatise on Invertebrate Paleontology 1(2). Geological Society of America, Boulder, and University of Kansas Press, Lawrence, p. S455-S495.

Ubaghs, G., 1967b, Le genre Ceratocystis Jaekel (Echinodermata, Stylophora): University of Kansas Paleontological Contributions, Paper 22, p. 1-16.

Ubaghs, G., 1969, Aethocrinus moorei Ubaghs, n. gen. n. sp, le plus ancien crinoïde dicyclique connu: University of Kansas Paleontological Contributions, Paper 38, p. 1-25.

Ubaghs, G., 1978, Skeletal morphology of fossils crinoids: in Moore, R.C. and Teichert, C. (eds.) Treatise on Invertebrate Paleontology, Part T, Echinodermata 2(1). Geological Society of America, Boulder, and University of Kansas Press, Lawrence, p. T58-T216.

Zamora, S., Lefebvre, B., Hosgör, I., Franzen, C., Nardin, E., Fatka, O., and Alvaro, J.J., 2015, The Cambrian edrioasteroid Stromatocystites; systematics, palaeogeography, and palaeobiology: Geobios, v. 48, p. 417-426. 
817 Zhao, Y., Sumrall, C.D., Parsley, R.D., and Peng, J., 2010, Kailidiscus, a new plesiomorphic 818 edrioasteroid from the Kaili biota of Guizhou Province, China: Journal of Paleontology,

$819 \quad$ v. 84, p. $668-680$.

820 
821 Table 1. Eumorphocystis specimens studied, with sizes of specimens, and comments on image 822 orientations used in this study.

823

\begin{tabular}{|c|c|c|}
\hline Specimen number & Thecal height (mm) & Images used \\
\hline OU holotype cast 3123 & 50 & not illustrated \\
\hline OU 9047 & 9.5 & A ray $2^{\text {nd }}$ broken floor plate left, $1^{\text {st }}$ on right \\
\hline OU 9048 & 20 & E ray, $1^{\text {st }}$ floor plate left, $2^{\text {nd }}$ on right \\
\hline OU 9049 & 21 & oral surface, $\mathrm{C}$ ray hemi-canal \\
\hline OU 238156 & 11 & not illustrated \\
\hline OU 238157 & 29 & A ray weathered, 3 rd floor plate, stem facet \\
\hline OU 238158 & 34 & not illustrated \\
\hline OU 238159 & 14 & not illustrated \\
\hline $1107 \mathrm{TX} 2$ & - & ? ray, $4^{\text {th }}$ floor plate from oral \\
\hline $1279 \mathrm{TX} 126$ & 28 & oral surface, $\mathrm{AB}$ oral, $\mathrm{B}$ ray hemi-canal \\
\hline 1279 TX339 & 7.5 & not illustrated \\
\hline 1404TX6 & 22 & C, weathered, $3^{\text {rd }}$ floor plate \\
\hline NPL 93144 & - & thecal wall and two pseudo-arm stubs \\
\hline
\end{tabular}


825 Table 2. List of taxa used in the phylogenetic analysis (expanded from Guensburg et al., 2020):

826

827 Basal pentaradiate echinoderm

828 Stromatocystites pentangularis Pompeckj, 1896

829 Kailidiscus chinensis Zhao, Sumrall, Parsley and Peng, 2010

830 Camptostroma roddyi Ruedemann, 1933

831 'Totiglobus' lloydi Sprinkle, 1985

832 Pseudedriophus guensburgi Sprinkle and Sumrall, 2015

833

834 Blastozoans

835 Kinzercystis durhami Sprinkle, 1973

836 Lepidocystis wanneri Foerste, 1938

837 Eumorphocystis multiporata Branson and Peck, 1940

838 Gogia kitchnerensis Sprinkle, 1973

839 Hemicosmites pocillum Jaekel, 1899

840 Macrocystella mariae Callaway, 1877

841 Rhopalocystis destombesi Ubaghs, 1963

842 Stephanocrinus gemmiformis Conrad, 1842

843

844 Stylophorans

845 Ceratocystis perneri Jaekel, 1901

846

847 Crinoids 
40

848 Aethocrinus moorei Ubaghs, 1969

849 Alphacrinus mansfieldi Guensburg, 2012

850 Apektocrinus ubaghsi Guensburg and Sprinkle, 2009

851 Athenacrinus broweri Guensburg et al., 2020

852 Carabocrinus treadwelli Sinclair, 1945

853 Eknomocrinus wahwahensis Guensburg and Sprinkle, 2003

854 Gaurocrinus nealli (Hall, 1866)

855 Glenocrinus globularis Guensburg and Sprinkle, 2003

856 Hybocrinus nitidus Sinclair, 1945

857 Proxenocrinus inyoensis Strimple and McGinnis, 1972

858 Titanocrinus sumralli Guensburg and Sprinkle, 2003

859 
860 Table 3. Matrix used in phylogenetic analysis. - = character state gap; ? = missing data.

861

862 Taxon

Character Number

863

$\begin{array}{llllll}11111 & 11111 & 22222 & 22222 & 33333 & 3333\end{array}$

864

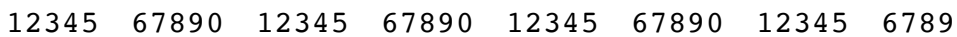

865

866

867

Stromatocystites pentangularis

$000000000-00-0-\quad-0-0-$

$-----$

$----\quad 0-000 \quad 0---$

Kailidiscus chinensis

000-0 0000- 10-0- -0-0-

$----\quad----\quad 0-0 ? \quad 0---$

868 Camptostroma roddyi

$0000000000 \quad 00-0-\quad---1000---\quad----\quad 0-0-0 \quad 0---$

869 "Totiglobus" Iloydi

870 Pseudedriophus guensburgi

00000 0010- 10-0- ---0- ---- ---- $0-000$ 0---

871 Kinzercystis durhami

872 Lepidocystis wanneri

873 Gogia kitchnerensis

874 Rhopalocystis destombesi

875 Macrocystella mariae

876 Hemicosmites pocillum

877 Stephanocrinus gemmiformis

878 Eumorphocystis multiporata

879 Ceratocystis perneri

880 Aethocrinus moorei

881 Alphacrinus mansfieldi

882 Apektocrinus ubaghsi

883 Athenacrinus broweri

884 Carabocrinus treadwelli

00000 0010- 11-0- -0-0-

$2-00 ?$ ?---

11111 -001- 00-0- -0-0- ----- ---- $1-000$ 0---

11111 -001- 00-0- -0-0- ----- ---- 1-00? ?---

11111 -001- 00-0- -0-0- ----- ---- 2-10? ?---

11111 -011- 04-00 -0-0- ----- ---- 3110? ?---

1111? -011- 13--0 -0-0- ---- ---- 3110? 1---

1111? -01?- 33--0 -0-0- ----- ----- 31101 1---

$1111 ?-011-\quad 15--0 \quad-0-0-\quad----\quad----31100 \quad 1---$

11111 -011- 23-00 -0-0- ----- ----- 31100 0---

00--1 0000- 00--- -1010 10100 ---00 0-00- ----

$00 ? 00 \quad 10001 \quad 12001 \quad 11111 \quad 10000 \quad 01110 \quad 420 ?-\quad-000$

$00 ? 00 \quad 10001 \quad 120110 ? 112 \quad 11002 \quad 11101 \quad 4200-\quad-001$

$00000 \quad 10001 \quad 12000 \quad 11110 \quad 10000 \quad-0010 \quad 4201-\quad-000$

$00000 \quad 10001 \quad 1201101112 \quad 11002 \quad 11101 \quad 4200-\quad$ - 001

00?-0 $10001 \quad 12001 \quad 10111 \quad 10111 \quad 12110 \quad 4201-\quad-000$

885 Gaurocrinus nealli

0-0?1 -1001 $12101 \quad 11111 \quad 11100 \quad 10100 \quad 320 ?-\quad-111$

886 Hybocrinus nitidus

$\begin{array}{llllllll}00000 & 10001 & 10001 & 11110 & 11111 & 12110 & 42010 & 2000\end{array}$

887 Eknomocrinus wahwahensi

00??0 $10001 \quad 12100 \quad 1 ? 111 \quad 10000 \quad 00000 \quad 420 ?-\quad-000$

888 Proxenocrinus inyoensis

00001 ??001 $12101 \quad 11111 \quad 11-00 \quad 10101 \quad 4$ ?0?- - 111

889 Glenocrinus globularis

00??0 $11000 \quad 1 ? 100 \quad 1 ? 111 \quad 10100 \quad 00000 \quad 420 ?-\quad-000$

890 Titanocrinus sumralli

$00 ? 00 \quad 11000 \quad 02000 \quad 01111 \quad 10100 \quad 00000 \quad 4200-\quad-000$

891 

Figure 3. Eumorphocystis multiporata Branson and Peck, 1940, specimens showing pseudo-arm

\section{Figure Captions}

Figure 1. Eumorphocystis multiporata Branson and Peck, 1940, partial reconstruction, from Parsley, 1982, included for orientation of subsequent images; by permission from The Paleontological Institute, The University of Kansas, Lawrence.

Figure 2. Eumorphocystis multiporata Branson and Peck, 1940, 1279TX338 (NPL 93144), large partial theca with two adjacent pseudo-arm stubs, one longer, one shorter. (1) Coated oral view showing long arm stub (left), pseudo-arm cover plates and brachial facet (just above and to right and above scale), sharp keeled brachioles folded orally, one brachial nearly complete to tip, proximal-most brachiolar short, wide, distal brachiolars with spinose processes and tiny biserial cover plates, tapering to sharp termination, nearby thecal plates bearing dense diplopores; (2) Coated end-on view of pseudo-arm in (1), broken at 7th floor plate beyond orals, tripartite arrangement, backing plate below, small ambulacral groove and cover plates above, larger ovate canal below; (3) Immersed short pseudo-arm stub and nearby theca, broken at distal margin of ?third floor plate from oral, showing (from bottom to top), anchoring thecal plate with diplopores, first backing plate, two sets of two blocky buttress plates forming a solid construct, floor plates surrounding small dark pore (above), and brachial stubs (see Fig. 5.3); (4) lateral view of pseudo-arm stub in (1) with backing plates (below), buttress plates filling wedge at thecal contact, large block-like, tumid, floor plates, and brachioles folded orally. canal and adjacent morphology. (1, 2) OU 9049, (1) oral view of theca, plates partly obscured by calcitic overgrowths, theca broken through $\mathrm{C}$ ambulacrum, arrow points to view of enlargement 
917 in 2 (2); (2) magnified view showing exposed suture surface with normally concealed small

918 hemi-canal running down ambulacral mid-line ambulacral mid-line just above thecal interior

919 (arrow); $(\mathbf{3}, \mathbf{5})$ TX1279.126, (3) oral view of well-preserved theca, thecal shoulder broken

920 through B ambulacrum (arrow) (5); (5) magnified view, AB oral showing long interradial suture

921 at center-right with vertical "half diplopores", short suture, BC oral, on left showing hemi-canal,

922 concealed in articulated examples, along mid-line of B ambulacrum (arrow); (4) OU 238157,

923 deeply etched theca, E ray showing apparent small weathered pore (arrow); (6) 1107TX2, AB

924 interray view, face of pseudo-arm broken at fourth floor plate, small canal almost entirely within

925 floor plates.

926

927 Figure 4. Eumorphocystis multiporata Branson and Peck, 1940, showing pseudo-arms and stem

928 facet. (1-3), three specimens showing small canals near thecal juncture; (1) OU 9048, E ray,

929 canal small, assumed to be spar-filled, (2) OU 238159, small individual lacking buttress plates

930 (see Fig. 5.1), (3) 1404TX6 C ray, from intermediate-sized individual with large buttress plates

931 below and small wedge-shaped elements intercalating above, these are missing splinters,

932 otherwise plates are visible in crevasses (unseen in image) (see Fig. 5.2); (4) OU 238157 stem

933 facet with inset peg and groove crenularium.

934

935 Figure 5. Arm to calyx transition of early crinoids for comparison with Eumorphocystis

936 morphology. (1, 2) Apektocrinus ubaghsi Guensburg and Sprinkle, 2009, 1983TX1, D ray arm

937 trunk to calyx transition, (1) original image, (2) color overlay interpretation, color coding (used

938 in Fig. 5 as well) for specific body wall regions as follows: Axial - orange $=$ floor plates, light

939 orange $=$ brachioles (floor plate extensions), blue $=$ lateral cover plates, purple $=$ medial cover 
940 plates; perforate extraxial - dark green = anchoring and backing plates, light green $=$ buttress

941 plate; imperforate extraxial — dark grey = brachials, light grey = laterals; (3) Aethocrinus moorei

942 Ubaghs, 1969, uncertain orientation, lateral plate field collapsed indicating expanding arm

943 coelomic cavity merging with main thecal cavity, floor and cover plates visible above, brachials

944 below.

945

946 Figure 6. Color-coded Eumorphocystis multiporata Branson and Peck, 1940, blastozoan feeding

947 appendage constructs shown with restorations of early crinoid arms. (1-3) E. multiporata

948 ontogenetic series (see Table 1), OU 238159, 1404TX6, and NPL 93144, respectively, pseudo-

949 arms broken off at theca-arm juncture, the second floor plate distal to the orals, small circular

950 canals within floor plates (for images, see Figs. 3.2, 3.3 and 1.3, respectively); (4) $E$.

951 multiporata, pseudo-arm broken seven floor plates distal to the orals, large ovate canal; $(\mathbf{5}, \mathbf{7})$

952 proximal arm cross sections of Titanocrinus and Apektocrinus, respectively; $(6,8,9)$ Three

953 blastozoan brachioles/arms with small canals, in cross section: rhipidocystid and Gogia spiralis

954 Robinson, 1965, brachioles (from Sprinkle, 1973), and uniserial Cambrian blastozoan arm (from

955 Clausen et al., 2009), respectively. Color coding: axial - orange $=$ floor plates, light orange $=$

956 brachioles (floor plate extensions), blue = lateral cover plates, purple $=$ medial cover plates;

957 perforate extraxial — dark green = radials and first backing plates, light green = buttress plates;

958 imperforate extraxial — dark grey $=$ brachials, light grey $=$ laterals.

960 Figure 7. Strict and 50\% majority rule consensus trees for parsimony analysis of data matrix in

961 Table 3. All node frequencies occur in 100\% of trees except where indicated, and bootstrap 
962 values are indicated by numbers in parentheses. See Summary of character analysis findings

963 below for definition of "pseudo-arm".

964

965 